研究ノ一ト

\title{
プラスチック表面のエッチングによる電気的性質の変化
}

\author{
長 坂 秀 雄* ·三友 明 夫*
}

\section{Etching Effect to Electrical Properties of Plastics Surface}

\author{
Hideo NAGASAKA and Akio MITOMO
}

\section{1. 実 験目的}

プラスチック表面の研究はプラスチックメッ キ，塗装接着，印刷適正などの問題を解明する のに役立つ。本研究では化学エッチング処理を 施したプラスチック表面の帯電特性と表面モレ 抵抗を調ベることにより，エッチングの進展度 と表面状態を知ろうと試みた。まずプラスチッ ク表面に打ける電荷の移動, すなわち電気伝導 は表面状態やふん囲気によって大さく変わる が，エッチングを施した場合どう変化するかを 調べた。合わせて表面の赤外吸収スペクトルと 顕微鏡による観察を行ない，電気的性質の变化を解析す る手段とした。

\section{2. 実 験方法}

実験に使用した試料は結晶性プラスチックのポリエチ レン（以下, PE と称す）と, 非晶性プラスチックのメ チルメタクリレート（以下, アクリルと称す）である。 試料寸法は直径 $35 \mathrm{~mm}$, 厚サ $1 \mathrm{~mm}$ とし, 成形用抜型で 作った。化学エッチングの処理条件は第 1 表であり, 処 理後は水洗をし, 空気中で乾燥した。

つぎに帯電特性測定用の試料は相対湿度 $(\mathrm{RH})<10 \%$ ふん囲気中へ，また表面モレ抵抗測定用の試料は $\mathrm{RH}=$ $=90 \%$ おび $100 \%$ のん囲気中に一定時間放固した後 測定試料とした。帯電特性の測定は第 1 図(a)に示す試作 装置により帯電量を表面電位として測定した。印加電圧 は直流の $6 \mathrm{kV}$ と，針対平板電極部でコロナイオンを プラスチック表面に注入した。スクリーン電極は針対平 板電極間の電界を平等にするために設けたすので，スク

* 茨城大学工学部（茨城県日立市中成沢町）

Faculty of Engineering. Ibaraki Univ.

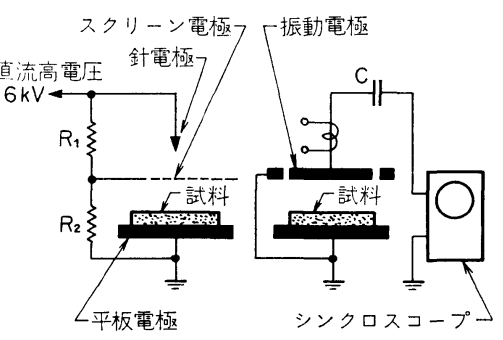

(a)

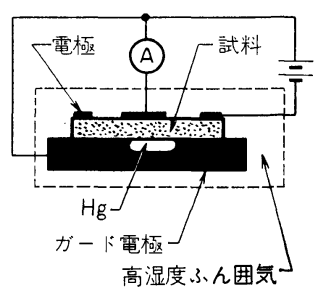

(b) 第1図帯電特性測定図(a)と表面モレ抵抗測定図(b)

リーンの位置, 網目の寸法によっても電界分布が変わる

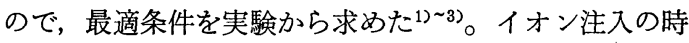
間は各エッチング試料とも10min とした。これは試作装 置と印加電圧の条件から電荷が飽和するまでの時間が 10 min であることから決定した。注入後試料は回転移動に よって振動容量型電位計部分に移し, 表面電位を検出し てシンクロスコープにより観測した。検出部の振動電極 は $50 \mathrm{~Hz} ， 0.5 \sim 2 \mathrm{~V}$ で振動する構造を有し，ガード電極 は端効果による不平等電界を補正するためである。

第 1 表 エッチング処理条件

\begin{tabular}{|c|c|c|c|c|}
\hline 試＼cjkstart料 & $J_{t}$ & \multicolumn{2}{|c|}{ P. E } & アクリル \\
\hline \multicolumn{2}{|c|}{ プレエッチング液 } & \multicolumn{2}{|c|}{ キシロール } & キシロール \\
\hline & 浴温 & & $60^{\circ} \mathrm{C}$ & $60^{\circ} \mathrm{C}$ \\
\hline & 時間 & & $10 \mathrm{~min}$ & $1 \mathrm{~min}$ \\
\hline \multirow{3}{*}{\multicolumn{2}{|c|}{ エッチング液 }} & $\mathrm{K}_{2} \mathrm{Cr}_{2} \mathrm{O}$ & $75 \mathrm{~g}$ & 3 号エッチング液 \\
\hline & & $\mathrm{H}_{2} \mathrm{SO}_{4}$ & $800 \mathrm{~g}$ & （奥野製薬） \\
\hline & & 水 & $120 \mathrm{~g}$ & \\
\hline & 浴温 & & $60^{\circ} \mathrm{C}$ & $60^{\circ} \mathrm{C}$ \\
\hline & 時間 & & $-30 \mathrm{~min}$ & $1 \sim 10 \mathrm{~min}$ \\
\hline
\end{tabular}




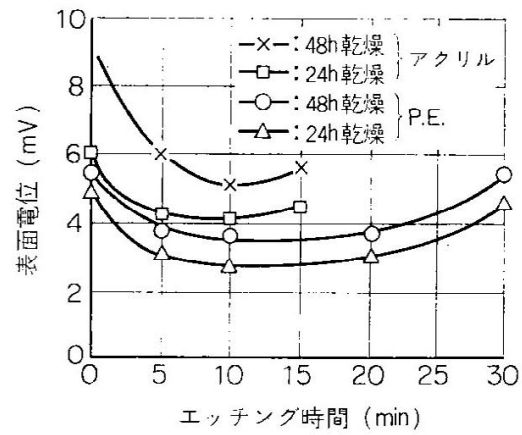

第2図エッチングによる带電特性の変化

表面モレ抵抗の測定は第 1 図(b)の回路で行なった。試 料の片面は導電染料を同じ円状に $10 \mathrm{~mm}$ の間隔で塗布し た。测定ふん因気は $\mathrm{RH}=90 \%$ \% $100 \%$ のデシケータ中 である。この実験も帯電特性の測定と同じく，エッチン グ時間の異なる試料を電気的に測定して，その違いを知 ろらとするすのである。

赤外吸収スヘクトル用の試料は0. 1〜0.2 $\mathrm{mm}$ の薄膜を 作り測定した。また顕微鏡観察によって表面状態の変化

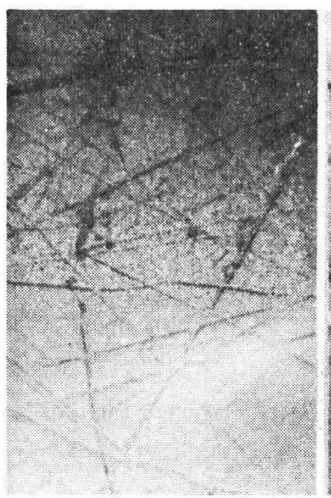

フリクル エッチング

$1 \mathrm{~min}$

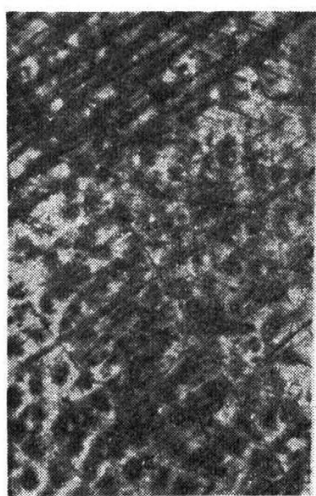

P.E. エッチング

$5 \mathrm{~min}$

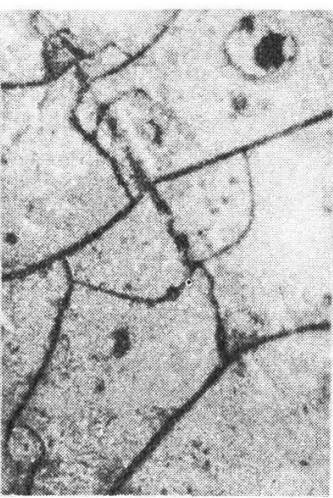

$5 \min$

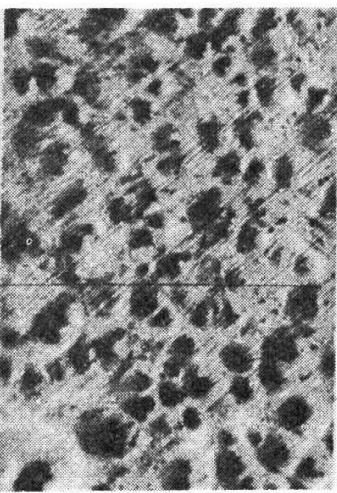

$10 \mathrm{~min}$

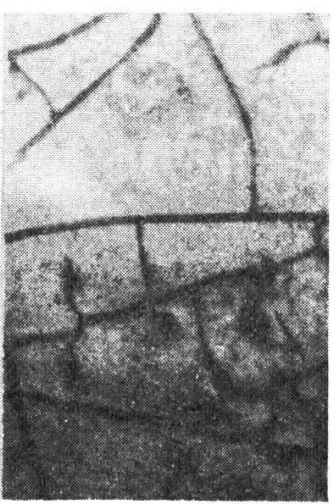

$10 \mathrm{~min}$

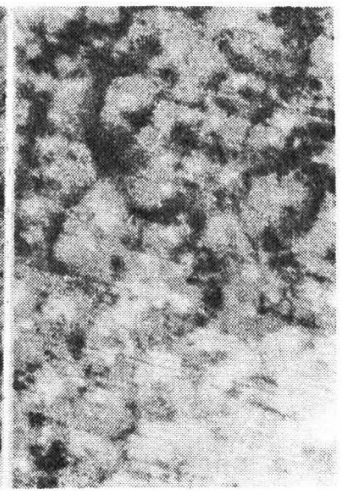

$20 \mathrm{~min}$
写真1 エッチングを施したプラスチックの粗化進展状況（X160）

\section{3. 実験結果および検討}

\section{3-1 実 験 結 果}

带電特性の测定結果を第 2 図 に示す。測定結果によると $\mathrm{PE，}$ アクリルとも帯電量の差はある が, エッチング時間によって, (エッチングの進行について) 帯電量の状態変化がつぎの 3 段 階に分けられることを認めた。 第 1 段階は表面電位が減少し, 第 2 段階で単調になり，最後の 段階でやや上暴する。また試料 の漧燥が長いほど表面電位が大 きく，高湿度中では小さい。 のことはブラスチックのエッチ ング表面が空気中の水分に大き く影警を受けることを示す。

つぎに表面モレ抵抗の測定結 果を第 3 図に示す。の测定結 果も顕著に 3 段階の変化を示し た。最初は抵抗が急激に減少 し, 中間で単調になり，最後に ふたたび急激な減少を示す。湿 度との関係に和いて， RH=90 \%では 3 段階の変化が明確であ るが, RH=100\%では中間の単 調変化がなく，急激な減少過程 である。また RHく10\%の場合 
エッチングによる抵抗変化の差は少ない。

P.E の遠赤外 $\left(650-4000 \mathrm{~cm}^{-1}\right)$ 吸収ス ペクトルを測定した結果が第 4 図である。 エッチングを施すと，エチル基の増加(762 $\left.\mathrm{cm}^{-1}\right)$, メチル基の増加 $\left(1378 \mathrm{~cm}^{-1}\right)$, カ ルボニル基 $\left(1530 \sim 1800 \mathrm{~cm}^{-1}\right)$ の吸収曲線 が得られた。

エッチング表面の顕微鏡による観察結果 を写真 1 に示す。結晶質と非晶質では異な

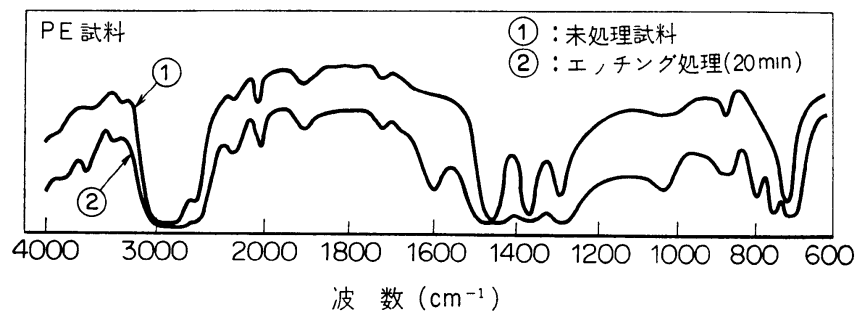

第4図 エッチングを施した PE の IR チングされている様子が観察された。 赤外吸収スペクトルの結果も合わせて考えると, エッ チングを施したプラスチック表面の電気伝導を支配する 因子として，

（i）表面層分子の低分子化により，新しい基が生成し て水分子の吸着性が増加したため。

(ii) 粗化による水分子吸着性の増大。

（iii）表面に付着している不純物。

(iv）ふん囲気の条件。

などが考えられる。上記のうち（i）はミク口的変化， (ii）はマク口的変化による電気伝導の変化と考えられ る。

(1972-3-15 受理)

（昭和46年 5 月，本協会第43回学術講演大会にて発表）

\section{文献}

1) 家田, 他, 電気学会誌, Vol. 88-6, No. 957(1968)

2) 田中, 他, 電気学会誌, Vol. 89-4, No. 967(1969)

3) 家田, 他, 電気学会誌, Vol. 84-5, No. 908(1964) の吸着が増加したと考えられる。エッチングされた最外 表面はかなりなめらかになり，つぎの表面が新しくエッ 